\title{
European Union Democracy Promotion and its impact on Civil Society in Central Asia ${ }^{1}$
}

\begin{abstract}
After a period of relatively small activity in this region, in 2007, the European Union offered a strategy for Central Asia. This strategy addressed many issues, including democratic deficit and human rights violations. The main obstacles to the implementation of the strategy are autocratic tendencies and corruption, the influence of neighbors strongly leaning towards autocracy and the postSoviet legacy. Additionally, the EU's activity is overshadowed by the US and has minimal capacity for pursuing its own policy toward Central Asia. Another problem is the fact that after implementing this EU strategy toward Central Asia there are no new initiatives which contribute to more visible European activity in that region.
\end{abstract}

Key words: European Union, Central Asia, authoritarianism, democratization, civil society

$\mathbf{T}$ he Soviet Union's collapse has enabled five states in Central Asia: Kazakhstan, Kyrgyzstan, Tajikistan, Turkmenistan and Uzbekistan to take a path towards independence. Within the central system of distribution managed from Moscow, each Soviet republic was assigned a specific role. In the Soviet system, Central Asia's role was to supply raw materials which were subsequently processed in Soviet republics to the west. Cotton and silk were accompanied by wheat and such natural resources as petroleum, natural gas, iron ore, uranium, non-ferrous metals and sulfur. Local production failed to meet local demand. Fuels, petroleum products, various machinery, appliances and consumables had to be brought from other parts of the Soviet Union. Local budgets generated losses and the region survived largely thanks to subsidies that paid for infrastructural investments, among other things.

Central Asia faced a considerable financial challenge in 1993, when the Russian authorities made a unilateral decision to dissolve the ruble zone. This created additional serious problems for the crumbling economies in Central Asia. Kazakhstan, Uzbekistan, Kyrgyzstan and Turkmenistan responded by introducing their own national currencies almost immediately, whereas Tajikistan was the last, having done so as late as in May 1995.

In the 1990s, Central Asian states found themselves in a dire situation and counted on Western states and the European Union to become more involved and help solve the financial and economic crisis in the region. The European Union's involvement at this most difficult time turned out to be more than modest, given its potential and the financial measures at its disposal. Brussels underestimated the scale of the geopolitical

1 The article was written as part of a project sponsored by the National Science Centre in Poland: "The European Union's attitude to Central Asia - regional and international determinants," no. 2014/15/B/HS5/01591. 
change that had taken place in the early 1990s on the territory of the former USSR. This was demonstrated, for instance, by the fact that Central Asia was treated as a component of the Commonwealth of Independent States. Russia and Ukraine were the priorities for the EU at that time. Out of all EU members, only the Federal Republic of Germany had diplomatic missions in each of the five Central Asian republics, whereas France and the UK had missions in a majority of them. The remaining EU member states used Ankara and Moscow as intermediaries.

For many years, the EU did not consider Central Asia as a strategic region, but this started to change after 2001.

When considering the EU's activities to promote democracy and form civil society in Central Asia, the following restrictions need to be noted:

1) insufficient economic, financial and political involvement of the EU in this region meant that it was hard to talk about the conditionality principle: providing aid in return for the implementation of the reforms demanded by the EU;

2) EU energy interests and security were a priority that prevailed over actively fostering democracy, especially in Kazakhstan and Turkmenistan;

3 ) the regimes in this region have a specific character as independence was not a result of democratization processes or opposition activity. Independence in Central Asian republics was frequently introduced by former Soviet elites, which thereby entrenched their power. This was particularly observable in Turkmenistan, Kazakhstan and Uzbekistan. Tajikistan faced a civil war in the period from 1992-95. The change in Kyrgyzstan occurred in the wake of political crises in 2005 and 2010. Central Asia is distinguished by such undesirable phenomena as centralization of power, subordinating various fields of socio-economic life to authorities and a high corruption index;

4) the opposition of Uzbekistan is formed by Islamic radicals. A political crisis there may lead to destabilization and the growth of a Jihadist network in the Fergana Valley. Despite their autocratic origin, in 2001, Uzbekistan, Kazakhstan and Kyrgyzstan launched active cooperation with the United States, became party to a counter-terrorism coalition and offered logistical support to the International Security Assistance Force (ISAF) mission in Afghanistan. The conviction that terrorism is a greater threat and even non-democratic allies should be sought has frequently prevailed. Autocratic leaders obtained additional justification for the expansion of their forces to combat the Islamic opposition, which posed a threat also to international security;

5) the authoritarian power systems in individual Central Asian states have been retained also because of such neighbors as Russia, China, Turkey and Iran. The political systems in the surrounding states can hardly be characterized as liberal.

Taking the above limitations into consideration, EU decision-makers should seek to identify the most efficient range of instruments and activities which could foster democracy in the five Central Asian states. It has to be taken into account, however, that the problems and limitations in fostering the principles of democracy and civil society are so serious that they arouse a number of concerns about the efficiency of this approach. Especially as other external actors, such as China and Russia, are interested solely in economic cooperation and do not burden their relations with Central Asian countries with such political matters as the liberalization of autocratic power systems. Another issue 
pertains to the model of democracy which is supposed to become a reference point. If the western model is chosen, can it be adapted to fit hierarchically organized societies where the Soviet command system turned out to have been so deeply rooted that there was no genuine political transformation after 1991. Systemic transformation encompasses three basic areas: economy, politics and society. Economically, transformation consists in the transition from a centrally managed economy to a market economy. Politically, it is the transition from an authoritarian, or even totalitarian system to a democratic one; and in social terms it is the reconstruction of a society formerly based on the principles of enforced collectivism into one characterized by individual activity. All these objectives were highly difficult to achieve.

As has already been mentioned, from the very beginning, Central Asia was of no strategic importance in EU policy. Initially, it was viewed as a whole and the differences between individual Central Asian republics were overlooked.

The cooperation between the EU and Central Asian states was institutionalized by means of Partnership and Cooperation Agreements (PCAs). It should be noted that such a PCA was signed between the EU and Central Asian states several years later than similar agreements with Russia and Ukraine respectively. The Partnership and Cooperation Agreement provided for a broad range of cooperation between the EU and partners within the Commonwealth of Independent States (CIS). The PCA declared the designing of an appropriate framework for developing political dialogue, support for democratization efforts and actions aimed at developing a market economy, promoting trade and investment, and defining a framework for legal, economic, social, financial, scientific, technological and cultural cooperation (PCA Kazakhstan, 1996). The PCAs concluded with Russia, Ukraine and Moldova respectively included a declaration that a free trade zone would be established between each of these countries and the EU in the future. Such a declaration was missing from the agreements concluded with Central Asian states.

The PCAs with Kazakhstan and Kyrgyzstan were signed in 1995, followed by an agreement with Uzbekistan one year later. Slowly, an awareness of the differences between the individual states of this region began to emerge.

Unfortunately, the proportion of resources allocated to Central Asia within the Technical Assistance for the Commonwealth of Independent States (TACIS) programme was less significant than in the case of other post-Soviet states. The programme operated for fifteen years before it was replaced by other aid measures. Initially, Russia and Ukraine were its greatest beneficiaries, receiving EUR 1.2 bn and EUR $460.8 \mathrm{mln}$ respectively. The resources dedicated to the five Central Asian republics amounted to as little as EUR $311.8 \mathrm{mln}$ (Delcour, 2011, p. 94). In the period from 1991-2010, ca. 300 projects were addressed at Kazakhstan amounting to a total of EUR 140 mln; Kyrgyzstan obtained EUR 130 mln (Hoffman, 2010, p. 97). Tajikistan turned out to be the greatest beneficiary of aid. After the end of the five-year-long civil war, Tajikistan received over EUR $500 \mathrm{mln}$ through different aid projects, including EUR $66 \mathrm{mln}$ under TACIS.

In terms of fostering democracy and civil society, TACIS did not meet the expectations associated with it. Although its declared objective was to support reforms and pursue a market economy, in practice it was sufficient to state that transformation would be implemented to obtain successive tranches of financial aid. The problem of the negligible influence of TACIS on the implementation of reforms and market economy was 
noted as early as in 1996. The EU Council responded by adopting an additional condition for the continuation of the programme. Article 3 provided that, in the case of a breach of democratic principles and human rights, the EU Council could be motioned by the Commission to suspend the programme by a qualified majority of votes (Kreutz, 2005, pp. 37-38). This solution was never resorted to, though, thereby confirming that the conditionality principle was a weak instrument. The limited efficiency of TACIS was addressed by Patricia Davis and Peter Dombrowski, who said that it "had little bite, while the procedures for their enforcement had proved to be extremely wieldy" (Davis, Dombrowski, 2000, p. 88). Even TACIS beneficiaries were critical of it. They complained about its limited financial scope and the lack of prospects for greater EU involvement in Central Asia. EU programmes were initially expected to facilitate a recovery from crisis in the region. Yet the 1990s brought disappointment to both parties. The EU had excessive expectations as to the pace of democratization and the development of civil society, whereas the beneficiaries were becoming increasingly critical about the insufficiency of the program, given their needs.

2001 marked an important caesura in the EU approach to Central Asian states. Washington considered this region to be of key significance for the launch of the ISAF peace mission in Afghanistan. This altered US attitude gave a new dynamic to EU activities aimed at Central Asia. Central Asian states were given an opportunity to maneuver between the US, Russia and China in order to obtain the best conditions for future cooperation. This strategic perspective had its limitations as it pushed the issue of political reforms to the background.

Given the smuggling of drugs from Afghanistan and terrorism, efficient border control and sealing the borders between Afghanistan, Kyrgyzstan, Turkmenistan and Uzbekistan, as well as between Central Asian republics became one of the key priorities. Therefore, the Central Asia Drug Assistance Programme (CADAP), which had been in place since 1996, was supplemented with the Border Management Programme in Central Asia (BOMCA) after 2001 (Matveeva, 2006, p. 96). The latter aims to facilitate crossborder cooperation, foster legal trade and the transfer of various goods, as well as secure the borders efficiently. At present, BOMCA is among the largest programmes financed by the EU; in the period from 2003-2014 its budget amounted to EUR $33.6 \mathrm{mln}$.

In June 2007, the Council of the European Union announced the Strategy for a New Partnership for Central Asia (The European Union and Central Asia: The New Partnership in action, 2009). The strategy also provided for activities fostering democratization processes and civil society. These issues had never been emphasized as long-term priorities in EU-Central Asia relations. For instance, in the period from 2002-2006, Brussels was focused on fostering trade, investments in the gas industry and the development of transportation in its relations with this region (Crawford, 2008, pp. 170-180). One such activity involved the alignment of Central Asian standards related to the requirements for hydrocarbons, to comply with EU standards. The EU financed various infrastructural projects at that time, in particular those related to the energy sector, which was allocated EUR $45 \mathrm{mln}$, and transportation, with EUR $29 \mathrm{mln}$ earmarked for this purpose. One of the objectives of the investment projects implemented within EU framework was to stimulate greater activity of European energy companies in this region. Another area of EU activities was launched under the Freedom, Security and Justice Programme 2002-2006, address- 
ing three issues: countering organized crime, management of borders and asylum policy. A total of EUR $112 \mathrm{mln}$ was allocated to these objectives. Additionally, an EU financial instrument operated in the period of 2002-2006 under bilateral collaboration projects. Out of EUR $142 \mathrm{mln}$, ca. $60 \%$ was allocated to countering poverty and exclusion, $20 \%$ - to fostering administrative reforms, and the remaining $20 \%$ was to be dedicated to civil society institutions; this amount was to be received not so much by human rights organizations but by institutions related to the public administration of individual Central Asian republics, aiming, for instance, to conduct training, rather than support independent civil society institutions (Crawford, 2008, p. 180).

The moment when the EU began to strongly emphasize human rights and democratization processes in Central Asian states was marked by 2007, when the above-mentioned strategy for Central Asia was announced. Launching this strategy was accompanied by structural changes in EU activity. The European Initiative on Democracy and Human Rights (1994-2006) was replaced by the European Instrument for Democracy and Human Rights (EIDHR) with an annual budget of EUR $140 \mathrm{mln}$. This new instrument was to address financing and aiding independent civil society organizations, also in Central European states, to a much greater extent (Axyonova, 2012).

EU strategy was addressed at the whole of Central Asia. It stressed continued support for existing activities, aiming to advance cooperation with individual states. The strategy emphasized that the following activities and initiatives would be implemented in order to foster democracy and economic welfare in Central Asia:

1) to use instruments, programmes, cooperation agreements and political dialogue efficiently;

2) to balance out bilateral solutions by means of the activities aiming to face up to joint regional challenges;

3) to give particular importance to the primary seven political areas: (a) good governance, rule of law, human rights and democratization; (b) education and training; (c) economic development, trade and investments; (d) transportation and energy; (e) environmental sustainability and water management; (f) handling common threats and challenges; and $(\mathrm{g})$ intercultural dialogue;

4) to increase the EU budget for the financial perspective 2007-2013 to EUR $750 \mathrm{mln}$ (Europejski Trybunał Obrachunkowy, 2013, p. 10).

The principal EU objective in relation to Central Asia was to become more visibly involved in this region. By virtue of the decision of the European Commission, towards the end of 2009, its branches in Kyrgyzstan and Tajikistan were transformed into fullyfledged EU delegations. Another delegation was established in Uzbekistan in 2012. Two years before announcing the Strategy, in 2007, the European Council appointed an EU Special Representative for Central Asia, whose principal tasks involved supporting good relations between the EU and Central Asian states, and fostering stability, cooperation, democracy and respect for human rights in this region, responding to key threats, in particular to specific problems that bring direct consequences for the EU and ensuring the increased efficiency and visibility of the EU in the region (Decyzja Rady 2016/596). The problem is that the office is located in Brussels rather than, for instance, Astana.

The resources allocated by the EU to developmental and humanitarian aid in Central Asia over the period from 1991-2013 amounted to EUR $2.1 \mathrm{bn}$, including EUR $750 \mathrm{mln}$ 
in 2007-2013. Initially, the funds were transferred through the TACIS programme, which was subsequently replaced by the Development Cooperation Instrument (DCI) in 2007. Another programme is the European Instrument for Democracy and Human Rights (EIDHR), accompanied by the Instrument for Stability (IfS) and the rapid response mechanism. Human rights and good governance are also supported by a third financial instrument for Non-state Actors and Local Authorities in Development (NSLA). The simultaneous launching of several instruments was in contrast to the earlier approach, involving the single and relatively modest TACIS programme (Emerson, Boonstra, 2010, p. 9). Although the EU increased the funds dedicated to Central Asia, they continued to account for a small proportion of total financial means addressed at this region. In the case of Kazakhstan, Turkmenistan and Uzbekistan, the official developmental aid offered from 2007-2013 accounted for under $5 \%$ of direct foreign investment per year (and less than $0.2 \%$ of GDP) (Europejski Trybunał Obrachunkowy, 2013, p. 12). The EU recognized that the states in this region still had a long way to go to achieve democracy and respect for human rights.

The strategy was based on cooperating with authoritarian governments and presidents of Central Asian republics who were not interested in profound transformations. After 1991, their method of reinforcing statehood in the internal and international context consisted in developing strong leadership in individual states in the region (Bodio, Załeski, 2008, p. 260). The politico-legal system has a hybrid nature. Despite the differences in their access to natural resources and the level of civil freedoms in respective countries, they share a lot of characteristics. The shape of their political and legal system was influenced by Soviet experiences, some elements of western democracies adapted to the local circumstances, authoritarian tendencies, local cultural determinants and the specific social structure in the countries in the region. In this system, a host of decisions related to policies, initiatives, activities and various programmes, as well as potential reforms is made by the president. Authoritarian tendencies occur to varying degrees in the presidential republics. Turkmenistan and Uzbekistan are the most authoritarian ones. The president of the latter, Islam Karimov, who had been in power since 1990, died in 2016 and power was formally assumed by the hitherto Prime Minister, Shavkat Mirziyoyev. He launched a number of reforms and normalized relations with the neighbors of Uzbekistan. This made Uzbekistan a spearhead of political transformations in the region which managed to depose corrupt and ineffectual presidents (McGlinchey, Project, 2011, pp. 80-88). Nevertheless, the attempts at changing political systems characterized by strong authoritarian tendencies, which are additionally coupled with ubiquitous corruption, have failed. Corruption is actually among the primary challenges which hinder development and modernization processes. On the basis of surveys conducted by Transparency International in 2016, Kyrgyzstan ranked 136, Tajikistan 151, Uzbekistan 156, Turkmenistan was the lowest at 154, whereas Kazakhstan was the leader in the region, placed 131 out of 176 countries examined for corruption (Transparency International 2017). Compared to its neighbors, Kazakhstan emerges as the most modernized state. The reforms successfully launched by President Nursultan Nazarbayev were related to granting numerous liberties to entrepreneurs. Combined with the proceeds from petroleum and infrastructure investments, these have triggered economic growth. This has initiated further reforms by the presidential circle aiming at increased professionalization of state officials, greater openness of the economy and the reduced role of the state in it, 
as well as curbing the extensive powers of the president in favor of legislative power and the government. The example of Kazakhstan shows that reforms can be initiated from the top to the bottom, by the leader of the state.

Among the different instruments provided for in the EU Strategy for 2007-2013, the development of higher education was to be supported under such programmes as Tempus, Erasmus Mundus Partnerships (Action 2) and Central Asia Research and Education Network (CAREN). Erasmus Mundus received the largest resources in 2007-2012 - EUR $195 \mathrm{mln}$, which made scholarships possible and the exchange of over 9,500 students and academic staff from Central Asia to be financed. The length of scholarships subsidized by the EU ranged from one month in the case of academics to fourteen, or even sixteen months for Master's students and doctoral candidates (Central Asia - Education and research). In the long run, the scholarships addressed at academic centers in the states of Central Asia were intended to produce personnel educated in EU universities. After 2013, subsidies for the development of academic exchange were curbed.

The EU strategy for Central Asia was not redefined after 2013. The EU continues to support democratic transformations and formation of civil society in this region, but this agenda is not accompanied by any serious instruments or programmes. Trade and energy interests are of utmost importance in relations with Kazakhstan, Turkmenistan and Uzbekistan, especially given increased involvement of Russia and China in this region, which is evidenced by such initiatives as the Russian Eurasian Economic Union and Chinese One Belt One Road.

\section{Conclusions}

Countries in Central Asia continue to struggle with numerous problems, including strong authoritarian tendencies, economic backwardness, excessive dependence on the proceeds generated by petroleum and gas exports, ethnic and clan conflicts, conflicts over water resources, smuggling of drugs, ubiquitous corruption and Islamic extremism. The region witnessed such serious crises as the civil war in Tajikistan in 1992-97, the authorities bloodily suppressing Uzbek protesters against corruption in Andijan in 2005 and ethnic conflicts in Osh in 2010. Democratization is hindered by the lack of tradition, the post-Soviet legacy and, last but not least, the authoritarian surroundings of China, Iran and Russia. Additionally, even the EU is not an entirely coherent actor. At present, the EU is facing crucial internal challenges posed by Brexit and separatist sentiments. In these circumstances the EU finds it difficult to be an efficient party to international relations and to present a convincing agenda to support democratic transformations in the EU's broader surroundings.

The hitherto cooperation between the EU and Central Asian countries has resulted in spectacular democratic transformations there. If political reforms have been implemented, these were mainly the result of internal rather than external factors.

Alongside these issues, there are also other factors which may hinder efforts aiming to support democratization processes and formation of civil society, namely:

1. For decades, Central Asia has not featured as a strategic area in terms of EU security; therefore the initiatives offered by the EU did not match the expectations aroused in 
the newly emerged independent Central Asian republics. This approach changed only partly, following US involvement and the ISAF mission in Afghanistan, as well as the problem with large-scale drug smuggling.

2. After 2014, the US gradually reduced its strategic activity in Central Asia, and the EU failed to propose a new strategy for this region. This shows that the EU is somewhat reluctant to play a more independent role in the politics in this region.

3. Another constraint is related to the fact that political and social stability depends on state leaders and their governance skills, rather than on political institutions which continue to play a secondary role in many cases.

4. The modernization process is too slow and superficial, thereby reinforcing backwardness and social tensions. The petrification of the authoritarian power system may result in individual countries becoming dependent on larger actors, such as Russia and China, and in further reinforcement of the authoritarian political system in Central Asia.

5. The 2007-2013 strategy proposed by the EU to Central Asia has been the prominent EU initiative in this region so far. It could have become the starting point for further EU involvement in this region, but not only did the EU fail to solve numerous problems, it actually slashed the scope of aid offered to this region.

6. A significant portion of EU resources was dedicated to academic mobility and exchange between universities. The programme enabled thousands of students and scholars from Central Asia to access European universities. After 2013, these mobility resources were considerably slashed. This undermined the concept of long-range changes to be implemented by the elite educated in the West.

7. One of the EU's problems concerns the overlapping competences of different EU initiatives and programmes addressed at Central Asia.

8. Various EU programmes offered to Central Asian countries and societies have brought negligible progress in supporting the activities of local authorities and non-governmental organizations. Neither authoritarian tendencies nor corruption have been successfully curbed and the latter remains to stay at the highest level in Central Asia as compared to other post-Soviet states.

9. Since 2014, the EU has not manifested any serious ambitions of greater involvement in fostering reforms, human rights and the formation of civil society.

\section{Bibliography}

Axyonova V. (2012), EU Human Rights and Democratisation Assistance to Central Asia: In Need of Further Reform, 10.09.2017.

Bodio T., Załęski P. (2008), Problemy budowy społeczeństwa obywatelskiego w państwach Azji Centralnej, in: Region Azji Centralnej jako obszar wpływów międzynarodowych, pod red. B. Bojarczyka, A. Ziętek, Lublin.

Central Asia - Education and research, http://ec.europa.eu/europeaid/regions/central-asia/eu-supporteducation-and-research-cooperation-central-asia_en, 20.10.2017.

Crawford G. (2008), EU human rights and democracy promotion in Central Asia: From Lofty principles to Lowly self-interests, "Perspectives on European Politics \& Society", 9, 2, pp. 172-191.

Davis P., Dombrowski P. (2000), International Assistance to the Former Soviet Union: Conditions and Transitions, "Policy Studies Journal”, no. 28(1). 
Decyzja Rady (WPZiB) 2016/596 z dnia 18 kwietnia 2016 r. przedlużajaca mandat Specjalnego Przedstawiciela Unii Europejskiej w Azji Środkowej.

Delcour L. (2011), Shaping the Post-Soviet Space? EU Policies and Approaches to Region-Building, Burlington.

Emerson M., Boonstra J. (2010), Into Euroasia: Monitoring the EU's Central Asia Strategy, Brussels: Centre for European Policy Studies (CEPS), Madrid.

Europejski Trybunał Obrachunkowy, https:/europa.eu/european-union/about-eu/institutions-bodies/ european-court-auditors_pl, 20.10.2017.

Gacek Ł. (2013), Azja Centralna w polityce energetycznej Chin, Wydawnictwo Uniwersytetu Jagiellońskiego, Kraków.

Hartman J. W. (2016), The May 2005 Andijan Uprising: What We Know, Central Asia-Caucasus Institute \& Silk Road Studies Program - A Joint Transatlantic Research and Policy Center, "Silk Road Paper."

Hoffman K. (2010), The EU in Central Asia: Successful Good Governance Promotion?, "The World Quarterly", no. 31(1).

Kozłowski K. (2012), Kolory Rewolucji, Poltext, Warszawa.

Kreutz J. (2005), Hard Measures by a Soft Power? Sanctions Policy of the European Union, "Policy Paper", no. 45, Bonn International Center for Conversion.

Lang J. (2013), The radical Islamic militants of Central Asia, New York.

Matveeva A. (2006), EU Stakes in Central Asia, "Chaillot Papers", no. 91, July, special issue.

McGlinchey E., Project M. (2011), Chaos, Violence, Dynasty: Politics and Islam in Central Asia, University of Pittsburgh Press, Pittsburgh.

Micklin P. (2007), The Aral Sea Disaster, “Annual Review of Earth and Planetary Sciences”, vol. 35, http://www.terras-altas.net.br/MA-2013/desastres\%20ambientais/AralSeaDisaster.pdf, 18.05.2017.

Olcott M. B. (2012), In the Whirlwind of Jihad, Brookings Institution Press, Washington, DC.

PCA-Kazakhstan, (1996), http://ec.europa.eu/external_relations/central_asia/pca/index_en.htm, 10.06.2017.

Perkowska A. (2013), Dezintegracja regionu Azji Centralnej jako pochodna uwarunkowań wewnętrznych, "Polityka i Bezpieczeństwo", no. 2.

Pomoc Rozwojowa dla UE dla Azji Środkowej (2013), Europejski Trybunał Obrachunkowy. Sprawozdanie Specjalne no. 13.

Rashid A. (1997), The New Great Game - the Battle for Central Asia's Oil, "Far Eastern Economic Review", 10 April.

Rashid A. (2003), Dżihad. Narodziny wojujacego islamu w Azji Środkowej, Warszawa.

Rocznik Strategiczny 2014/15 (2015), Przeglad sytuacji politycznej, gospodarczej $i$ wojskowej w środowisku międzynarodowym Polski, t. 20, Warszawa.

Sikorski T. (2010), Masakry etniczne w Kirgistanie przyczyny oraz reakcje międzynarodowe, "Biuletyn" Polskiego Instytutu Stosunków Międzynarodowych, no. 98, Warszawa, http://www.pism. pl/zalaczniki/Biuletyn_706.pdf, 15.05.2017.

Słojewska A., Wielkie bitwy o wode, http://www.rp.pl/artykul/1035598-Wielkie-bitwy-o-wode.html\#ap-2, 17.05.2017.

Stein M. (2012), Uzbekistan's View of Security in Afghanistan After 2014, "Military Review”, vol. 92, issue 3.

The European Union and Central Asia: The New Partnership in action (2009); http://eeas.europa.eu/ central_asia/docs/2010_strategy_eu_centralasia_en.pdf, 10.10.2017.

Transparency International (2016), http://www.transparency.org/country\#TKM.

Voloshin G. (2014), The European Union's Normative Power in Central Asia: Promoting Values and Defending Interests, New York. 
Wiśniewska I. (2013), Integracja euroazjatycka - rosyjska próba ekonomicznego scalenia obszaru poradzieckiego, "Prace OSW" nr 44, Warszawa.

World Drug Report (2013), United Nations on Drugs and Crime, Vienna.

\section{Wspieranie przez Unię Europejską demokratyzacji i jej wpływ na społeczeństwo obywatelskie w Azji Centralnej}

\section{Streszczenie}

Po 1991 r. region Azji Centralnej nie był priorytetowym obszarem w polityce zewnętrznej Uniii Europejskiej. W 2007 r. zaproponowana została wobec regionu Azji Centralnej strategia, w której odniesiono się do różnych problemów, w tym deficytu demokracji i łamanie praw człowieka. Okazuje się, że nie udało się zrealizować żadnego z zakładanych celów strategii. Powodem takiej sytuacji są silne tendencje autorytarne i korupcja, mało spójne proponowane rozwiązania oraz oddziaływujące otoczenie autorytarne sąsiadów i postradzieckie dziedzictwo. Istotnym ograniczeniem działań UE jest występowanie w cieniu USA oraz brak ambicji by także rozwijać współpracę w innych obszarach jak bezpieczeństwo czy zwiększenie europejskich inwestycji. Kolejnym problemem jest po zakończeniu jedynej strategii brak nakreślenia priorytetów, które umożliwiłoby UE na odgrywanie większej roli w Azji Centralnej.

Słowa kluczowe: Unia Europejska, Azja Centralna, autorytaryzm, demokratyzacja, społeczeństwo obywatelskie 